\title{
Kirill Glebovich Mikhailov: On the occasion of his 60th Birthday
}

YURI M. MARUSIK \& VLADIMIR BLAGODEROV (EDS)

5

Foreword

YURI M. MARUSIK \& VLADIMIR BLAGODEROV

6 Biography

YURI M. MARUSIK \& VICTOR FET

13 An annotated checklist of the insectivores (Mammalia, Eulipotyphla) of Laos

ALEXEI V. ABRAMOV

26 Review of the Epeolus tarsalis species group (Hymenoptera: Apidae, Epeolus Latreille, 1802), with description of a new species

YULIA V. ASTAFUROVA \& MAXIM YU. PROSHCHALYKIN

37 A new species of Galumnella (Acari, Oribatida, Galumnellidae) from Mozambique SERGEY G. ERMILOV \& MAREK BĄKOWSKI

45 Glebych minutissimus gen. et sp. nov., the smallest cobweb spider (Araneae: Theridiidae) KIRILL Y. ESKOV\& YURI M. MARUSIK

54 Three new species of Olivierus (Scorpiones: Buthidae) from Kazakhstan and Uzbekistan VICTOR FET, FRANTIŠEK KOVAŘÍK, BENJAMIN GANTENBEIN \& MATTHEW R. GRAHAM

73 Notes on the spider genus Dysdera Latreille, 1804 (Araneae: Dysderidae) in Central Asia ALEXANDER A. FOMICHEV \& YURI M. MARUSIK

90 Probles mikhailovi, a new enigmatic species of Tersilochinae (Hymenoptera: Ichneumonidae) from Madagascar

ANDREY I. KHALAIM

95 A new species of the genus Dorytomus Germar, 1817 (Coleoptera, Curculionidae) from Rovno amber ANDREI A. LEGALOV, VITALIY Y. NAZARENKO \& EVGENY E. PERKOVSKY

101 A new species of the genus Petersenidia Lelej (Hymenoptera: Mutillidae) from Indonesia, eastward of Wallace's line ARKADY S. LELEJ

106 A new species of Plectrocnemia (Trichoptera: Polycentropodidae) from Rovno amber STANISLAV I. MELNITSKY, VLADIMIR D. IVANOV \& EVGENY E. PERKOVSKY

110 Notes on the genus Chinattus Logunov, 1999 from India, Pakistan and Nepal (Arachnida: Araneae: Salticidae)

DMITRI V. LOGUNOV 
121 A review of the spider wasp genus Austrosalius Turner, 1917 (Hymenoptera, Pompilidae), with the description of a new species

VALERY M. LOKTIONOV

127 The hidden diversity of the genus Lyurella Derzhavin, 1939 (Crustacea: Amphipoda: Crangonyctidae): four new species from the subterranean habitats of the northwestern Caucasus, Russia IVAN N. MARIN \& DMITRY M. PALATOV

169 The new species Gorytes mikhailovi sp. nov. from Kazakhstan with a key to the Palaearctic species of Gorytes Latreille, 1804 (Hymenoptera: Apoidea: Crabronidae) MIKHAIL V. MOKROUSOV \& MAXIM YU. PROSHCHALYKIN

180 New data on the pygmy grasshopper genus Epitettix Hancock, 1907 (Orthoptera: Tetrigidae) SERGEY YU. STOROZHENKO

189 Protomauroania mikhailovi-a new species of malachite beetles (Coleoptera, Dasytidae) in Rovno amber

SERGEI E. TSHERNYSHEV \& EVGENY E. PERKOVSKY

195 Resurrection of the spider genus Bucliona Benoit, 1977, with a description of a new species from Kenya (Araneae, Clubionidae) JIANSHUANG ZHANG, YURI M. MARUSIK, AMBATA D. OKETCH, ESTHER N. KIOKO, HAO YU \& SHUQIANG LI

208 A new species of Raveniola (Araneae, Nemesiidae) from Western Tien-Shan SERGEI ZONSTEIN 